\title{
CLOTHING THE ELITE? PATTERNS OF TEXTILE PRODUCTION AND CONSUMPTION IN ANCIENT SUDAN AND NUBIA
}

\begin{abstract}
The Kingdom of Meroe (300 BCE-350 CE) developed a truly unique textile tradition, represented by hundreds of preserved fabrics, tools and iconographic representations. Together, this vast body of historical data provides a great opportunity to study patterns of textile production and consumption in the Meroitic society. This paper will first focus on restoring textile implements to their archaeological locations in order to identify the different contexts and scales of textile manufacturing, primarily spinning and weaving. Far from homogenous, the Meroitic textile industry reflected the social complexity and the ethnic diversity of the kingdom. The paper's second part will thus relate the settlement data on textile production to the finished products - fabrics and clothing - discovered in graves and depicted on reliefs and statues, thereby linking the textiles to the individuals using them. The role of the administrative and religious elite will particularly be discussed, both as commissioners and consumers of specific textile goods, as well as official relays in a state-controlled industry.
\end{abstract}

Keywords: archaeology, ancient Sudan and Nubia, Meroe, textiles, costumes, social display

\section{Introduction}

The Meroitic civilisation left us many impressive temples, pyramids and large cemeteries along the Middle Nile valley that all attest to the vivacity of the kingdom, governed by a powerful royal family and an important class of nobles. Despite this rich archaeological heritage, there are still many unknowns about the Meroitic society, its cultural identity, ethnic composition and different economic dynamics that sustained its population. In the absence of relevant historical texts, material studies provide a new range of evidence able to document these important aspects. Preserved in the dry sands of Sudan and Nubia, thousands of textile fabrics, tools, and iconographic representations of people in various costumes offer a unique opportunity to trace textile production from the very beginning of the textile chaîne opératoire to the many uses of the cloths, all the way to their final interment. As we follow the textile's life cycle, we also touch upon many key historical issues, such as agricultural practices, the organisation of labour and trade, and the definition and communication of social status. This paper will make use of this formidable corpus of evidence to shed new light

* Marie Skłodowska-Curie postdoctoral fellow, Centre for Textile Research, Saxo Institute, University of Copenhagen. TexMeroe project, EU H2020-MSCA 743420; (D https://orcid.org/0000-00020934-8367; elsa.yvanez@gmail.com on the economic system and cultural fabric of the Meroitic kingdom.

The Meroitic kingdom encompassed a large territory inhabited by various population groups ${ }^{1}$ stretching from the vast plains of the Blue and White Nile regions, through the savannahs of Central Sudan, and all the way north to the Nubian desert and the modern Egyptian border. Placed under the central authority of the royal family at Meroe, these diverse regions were governed by an extensive body of nobles in charge of the administrative and religious organisation of the kingdom. ${ }^{2}$ Closely related to the capital, these individuals formed a dominant elite class, whose members were distributed all over the Meroitic territory and acted as local proxies for the royal power. Their graves, located underneath small pyramids in elite cemeteries, have revealed many preserved fabrics, private statues and stelae that all display a specific textile style unique to the Meroitic production. Excavations in the settlements that housed these noble families have also shown many tools used for textile manufacturing, such as spindle whorls and loom weights. Together, this body of evidence indicates a strong link between textile production and the Meroitic elite.

\footnotetext{
${ }^{1}$ E.g. Welsby 1996; Baud 2010a.

${ }^{2}$ Török 1977; Török 1979; Török 2002.
} 

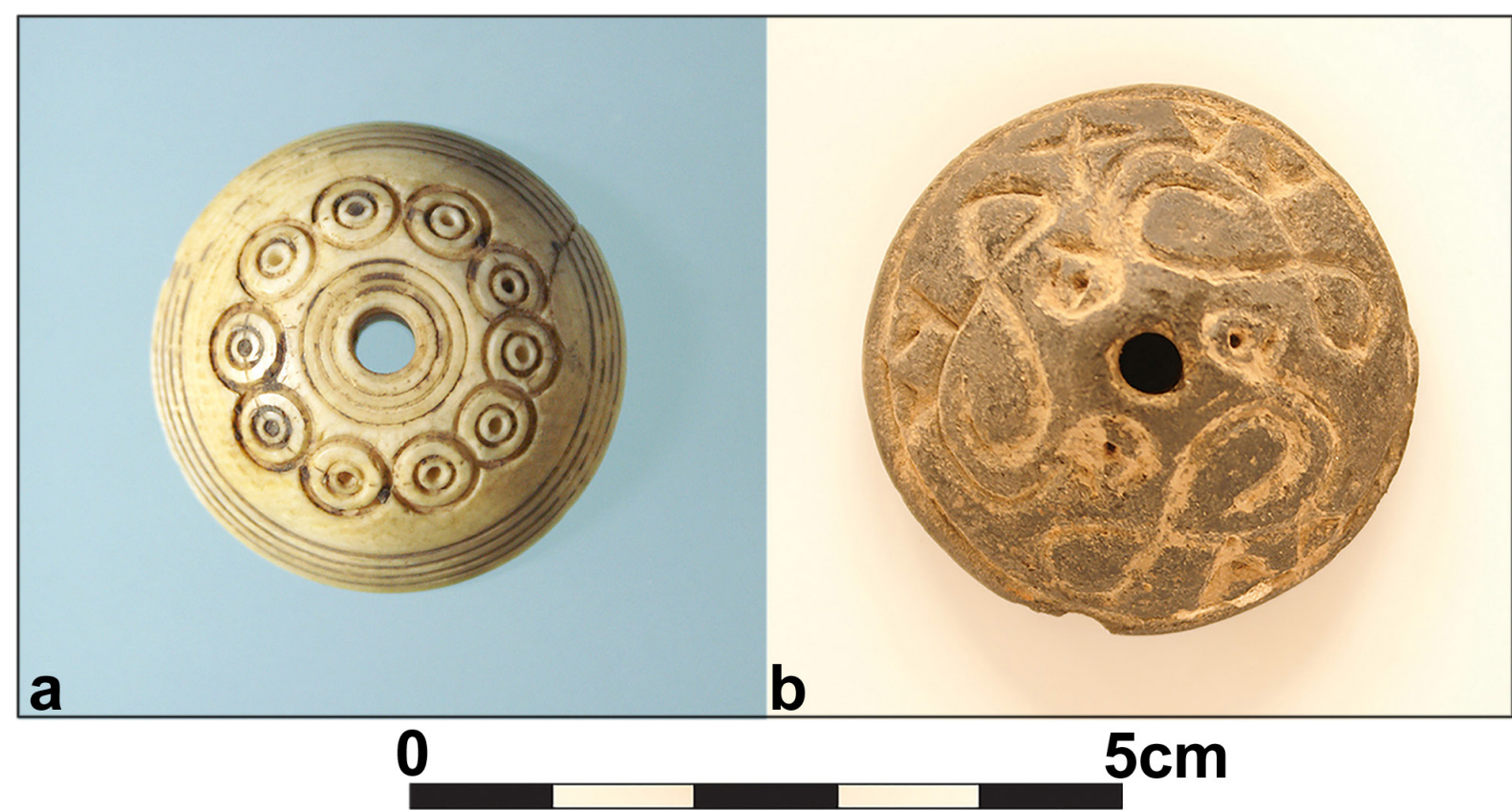

Fig. 1. Spindle whorls: a - Bone or ivory specimen, from Karanog grave $\mathrm{n}^{\circ} 468$. Courtesy of Penn Museum, image E7677; $\mathrm{b}$ - Ceramic specimen from Meroe, industrial quarter (north mount), decorated with bird patterns filled with white pigments. Sudan National Museum 24519. Photos E. Yvanez.

\section{Textile tools in context: from a domestic production to a small scale industry}

First of all, it is important to characterise the Meroitic textile production, assess its scale and identify its nature. Despite the great number of preserved tools, this essential task remains difficult to achieve because of our imprecise knowledge of the Meroitic urban world. A large part of the living quarters have completely disappeared from the archaeological record. On the one hand, pastoralists and semi-nomadic populations did not leave many traces of their temporary camps while, on the other hand, it is probable that most of settled farmers and craftsmen lived in light structures, built of organic material, in close proximity to the ever-changing course of the Nile. Our knowledge of economic activities is therefore limited to the brick-built settlements which housed official institutions. Nevertheless, ongoing excavations at those sites are now helping to further our understanding of the organisation and functioning of these towns. ${ }^{3}$ Besides the political and religious centres, funded under the patronage of the rulers, craft production seems to have been an essential component in the development of the urban grid. Dedicated quarters, mixing domestic and industrial features, are regularly identified at the periphery of the official centres. Objects discovered in the rooms, passageways and refuse deposits indicate the practice of various crafts, such as the manufacturing of faience, glass, metal, pottery and textiles.

\footnotetext{
${ }^{3}$ Baud 2010b
}

\section{Material sources}

While masses of iron slags still dot the landscape over the city of Meroe, thereby attesting the past presence of metallurgic activities, ${ }^{4}$ the textile craft requires a finer approach. Remains left by textile manufacturing are small in size and few in number, resulting from the natural degradation of the wood that formed most of its main tool, the loom. However, spindle whorls found in Central Sudan and Upper Nubia were primarily made of ceramic (cf. Fig. 1:b), and together with clay loom weights, form good indicators of the location and scale of textile activities such as spinning and weaving. ${ }^{5}$ Lower Nubian spindle whorls, made of turned wood or bone (cf. Fig. 1:a) and reminiscent of their contemporary Egyptian counterparts, have also survived quite well in both settlements and cemeteries. ${ }^{6}$ Other material sources to consider are small wooden or bone picks which have often been found in urban contexts and associated with weaving. ${ }^{7}$ Their exact use remains unclear and is still open to debate, but such picks would have been particularly helpful during textile making to pack weft threads on small portions of the weave, especially in tapestry.

While modern excavations provide us with clear records of objects and their findspots, older archives can also offer a trove of information, albeit not always complete and

\footnotetext{
${ }^{4}$ Humphris 2014.

${ }^{5}$ Yvanez, forthcoming. For studies of textiles implements in archaeological contexts see Gillis and Nosch 2007; Andersson Strand and Nosch 2015.

${ }^{6}$ Yvanez 2016.

${ }^{7}$ Kemp and Vogelsang-Eastwood 2001, 358-373.
} 
requiring additional detective work. In both cases, the examples of perfectly-preserved in situ textile installations are rare. Tools are seldom associated with one specific context of floor level. It is particularly true in dense habitation quarters and towns where many centuries of continued occupation and blowing sands have obscured the stratigraphy. Yet, a careful study of selected contexts of discovery can offer engaging elements of interpretation on the organisation of the textile craft and its relation to the Meroitic elite.

\section{Organisation and status of textile activities}

It is important to note that no formal textile workshop has been securely identified yet in Meroitic Sudan. Archaeology provides us with two possible examples of textile production centralised within one building: the first case - in the lower Nubian settlement of Ash-Shaukan ${ }^{8}$ - remains unstudied and hypothetical, while the second case shows an absolutely unique grouping of textile tools and fabrics inside the Isis shrine of Qasr Ibrim. ${ }^{9}$ These two hapax are both located at the northern extremity of the Meroitic territory, in modern Egypt, and present very specific features that prevent the generalisation of this tenuous evidence to the rest of the Meroitic kingdom. Despite the concentration of tools in a single structure, the two sites do not indicate that the buildings were exclusively reserved to textile production or that they housed professional workers. In the current state of our knowledge however, we cannot completely dismiss the existence of textile workshops in Lower Nubia.

It is also difficult to know who was making textiles in the Meroitic society, as there is no representation of people engaged in textile-related activities, nor in any other craft. An interesting clue comes from Lower Nubian cemeteries, especially the necropolis of Karanog. Found among the funerary assemblage of this elite population were 32 spindle whorls made of turned wood and bone or ivory (Fig. 1:a). ${ }^{10}$ These small tools, carefully crafted and decorated with lines and pointed circles, appear in the graves where at least one female individual had been interred, sometimes accompanied by personal care objects such as metallic tweezers and kohl tubes. It is then natural to assume that spinning had been recognised as a valued occupation for Karanog noble women, as it has appeared in various other past cultures. ${ }^{11}$ The value accorded to spinning is also exemplified by the elaborate ornamentation given to ceramic spindle whorls found in Central Sudan and the Gezira. ${ }^{12}$ Made of burnished ceramic, they were decorated with incised or impressed patterns, often apotropaic in nature and enhanced by white or red pigments (Fig. 1:b).

\footnotetext{
${ }^{8}$ Jacquet 1971, 127.

${ }^{9}$ Adams 1987; Driskell et al. 1989.

${ }^{10}$ Wooley and Maciver 1910, passim.

${ }^{11}$ Barber 2007, 173; e.g. in Bronze Age Italy, Gleba 2008, 173-178.

${ }^{12}$ Yvanez 2016, 166-171.
}

Contexts of textile activities: a case-study from Meroe

Most spindle whorls discovered at Meroitic sites have come from settlements, more specifically from royally funded cities with a palace, temples and administrative buildings. Significant numbers are attested in Central Sudan, in the capital city of Meroe and in other cities such as El-Hassa, Mouweis, and Hamadab. It is also true for the sites of Saqadi and Abu Geili, in the Gezira and Blue Nile regions, where thousands of spindle whorls were reported despite our very succinct knowledge of the area. ${ }^{13}$ In these settlements, textile implements appear in varying numbers in both domestic and mix-industrial quarters. This article will use Meroe-city as an example of different scales of textile production.

At Meroe, the tools were mainly discovered between 1965 and 1984 during P. L. Shinnie's excavations and, to a lesser extent, during earlier works conducted by J. Garstang in the Amun temple. ${ }^{14}$ Dispersed throughout several museums, ${ }^{15}$ the corpus today regroups about 250 spindle whorls, 110 loom weights, one needle, and one spool with cotton threads still attached. ${ }^{16}$ This corpus of material forms the second largest group of textile-related tools found in Sudan, behind the Abu Geili spindle whorls. Studying the archives, it was possible to locate the original findspots of most of the tools, mainly along trenches and test pits. Their repartition is as follow:

- Ceramic ovens area inside the Amun temple's temenos (M260): 12 spindle whorls.

- Iron scories Mount H: seven spindle whorls and two loom weights (test pit).

- Trench TT6, domestic levels: 38 spindle whorls, 22 loom weights, and one needle.

- North mount, domestic and industrial occupation levels: 128 spindle whorls, 79 loom weights, and one spool.

On Mount H and in Trench TT6, the profile of textile production is clearly domestic. The spindle whorls and loom weights were found scattered through several buildings and occupation layers, or in refuse deposits. The houses contained many small rooms and cooking installations, and showed phases of continuous occupation and refurbishment dated to the Early Meroitic period, all the way through the Late Meroitic period (c. 200 BCE-350 CE). Both spinning and weaving were practiced within these residential structures. The excavation of two Early Meroitic houses supplied

\footnotetext{
${ }^{13}$ Yvanez 2016; Yvanez, forthcoming.

${ }^{14}$ Shinnie and Bradley 1980; Török 1997; Shinnie and Anderson 2004

${ }^{15}$ Sudan National Museum and Khartoum University in $\mathrm{Su}-$ dan, Petrie Museum (UCL) in London, U.K.

${ }^{16}$ At the time of this study, I was unfortunately unable to locate any loom weight, nor the needle and spool, which whereabouts remain unknown. Further investigations in the site storage rooms and in the Khartoum University collections, as part of the Meroe Archival Project, might increase and precise the present list (A. Boozer, pers. comm.).
} 
in situ tools: six spindle whorls and two loom weights were found in House J/I 50 (Level 1) and three spindle whorls and one loom weight were recovered from House H/G 50 . The relatively low number of tools found over a long occupation period indicates a small-scale textile production, most probably destined to the family's own consumption.

On the other hand, the trenches dug into the northern part of the North mount revealed numerous textile implements (128 spindle whorls and 79 loom weights listed), discovered within a dense urban network of square or rectangular building units separated by narrow alleys. The implements were scattered over different structures, inside intrusive layers of abandonment or in refuse deposits. While a lot of these come from multi-functional areas linked to cooking and food storage, several groups of tools are, however, associated with more specific spaces. For example, an interesting group of c. 30 spindle whorls was discovered on an openair terrace located in front of large dwellings, together with traces of other crafts such as minor metallurgy and faience making. This particular area seems to have been used as a multi-functional public space, where Meroe's inhabitants could practice small crafts and industries. Spinning, a very portable activity, would have been particularly suited to this type of multifunctional open space. Another group of textile implements, composed of 18 spindle whorls, three loom weights and one needle, was also discovered in Building IA, an imposing structure defined by a high number of small storage rooms and a peculiar hydraulic installation in its courtyard. The exact function of this feature remains unfortunately unknown, but its construction identifies the building as an artisanal facility where textiles activities occupied an important role.

At Meroe, textile production seemed to have followed two different models:

- A domestic production, represented by small assemblages of textile tools, and attested in living quarters often in conjunction with food preparation. We can postulate a limited production output and the absence of specialised installations or workers.

- A small scale industry, represented by a higher number of tools, and attested in multifunctional industrial areas suggesting the involvement of more experienced, possibly semi-specialised weavers, and the production of a small surplus.

Of course, these schematic hypotheses are only relevant for Meroe itself and remain to be tested elsewhere taking into consideration the nature of the settlement. Other types of task-oriented towns could present different kinds of evidence. It is for example the case for the small Nubian establishment of Tila Island, used as a way station on the Nile trade route, and the town of Qasr Ibrim where numerous temples and traces of pilgrimage stand alongside important storage and artisanal facilities. While different in nature and unique in the Meroitic archaeological landscape, these two settlements were both heavily engaged in textile manufacturing and likely producing a sizable surplus of woven fabrics. ${ }^{17}$

\section{Control of textile production?}

The questions that arise from this panorama are whether this surplus was intended for a specific population group and whether this small industry was partially, or totally controlled by the authorities. Unfortunately, the available documentation remains silent on the answers to these questions. A set of 109 loom weights has been unearthed in the storage magazines of the Wad ben Naga palace, ${ }^{18}$ but there remains little evidence to clarify whether weaving was exclusively carried out for the palace's own consumption or the fabrics were to be redistributed to the royal family and the nobles. A tenuous clue can be found in the spindle whorls' decorations; in Central Sudan and the Gezira, the ceramic spindle whorls are almost always decorated with incised or impressed patterns, often with apotropaic designs. ${ }^{19}$ These standardised décors are closely related to the techniques and motifs of fine pottery bowls and jars used in religious and funerary contexts. Many sherds of such fine ware ceramics were even found together with several spindle whorls, e.g. within the Amun temple's ceramic oven at Meroe. ${ }^{20}$ Since the production of these luxurious items is attested in connection with Meroitic official institutions, ${ }^{21}$ I propose to interpret the standardised decoration of the spindle whorls as an indication of a certain degree of production control.

Far from being conclusive, the data from the textile implements forms a dense web of evidence that shapes an interesting - if still vague - model of textile production. As witnesses of textile consumption, the many pieces of clothing preserved in the graves of Meroitic officials bring an invaluable counterpoint to this investigation.

\section{Patterns of textile consumption: costume and social status}

Worn by the elite all throughout the Meroitic kingdom, these cloths and their very distinctive style strongly relate textile production to the highest members of the Meroitic society. Before going any further, an honest look at the available material compels me to recognise that this link is a de facto result of our own archaeological practice. The same discrepancy of sources previously noted for settlements also applies to the textile-rich cemeteries, where those best preserved belonged to the Meroitic elite. Often placed outside the agricultural and urban areas, on promontories or over wadis on the desert fringe, the graves topped with small pyramids and tumuli received the most attention from archaeologists. The same is

\footnotetext{
${ }^{17}$ About textile production at Qasr Ibrim, see Adams 2007; Adams and Adams 2013, 74, 107-116. For Tila Island, see Yvanez, forthcoming; Edwards 1996.

${ }^{18}$ Sudan National Museum 62.10.148, unpublished.

${ }^{19}$ Yvanez 2016, 166-171.

${ }^{20}$ Török 1997, 173-174, P1. 144.

${ }^{21}$ Edwards 2004, 169-173. For a panorama of Meroitic ceramic traditions, see Evina 2010.
} 
true for iconographical sources where reliefs, statues, stelae and painted ceramics tend to be commissioned by and representative of the royal and noble classes. As a result, little is known about the rest of the population, its ethnicity and its social organisation. Studying this issue very quickly leads to an archaeology of the absent: ${ }^{22}$ absent houses, absent artefacts, absent funerary remains and grave goods able to tell us the story of these populations. Keeping all components of the Meroitic society in mind is nonetheless essential to understanding its different groups and their inter-dynamics. There can be no discussion of elite costume without consideration for their non-elite counterparts, and no hierarchy of material classes without the underlying past desire for social differentiation. As clothing transcribes both individual and social parameters into tangible features, the study of textiles and costumes is an effective channel to explore the diversity of the Meroitic society.

\section{Nakedness and body acculturation processes}

Drawing on the concept of absence, one significant feature of the Meroitic body is its nakedness. Often reported by classical authors, nudity is used as an argument to prove the inferiority of populations living outside the Roman world. In these texts, bare skin and animal products became allegories of the uncivilised.

As for clothing, some of them have none at all, but lived naked all the time; only against the burning sand do they provide themselves protection by whatever means is at hand. Some cut the tails off the behind of their sheep and cover their hips with them, letting it hang down in front like private parts. Some also use the hides of their animals, other cover the body as far as the waist with girdles which they plait from the hair of the animals.

Agatharchides, On the Erythrean Sea, copied by Diodorus of Sicily, $2^{\text {nd }}$ c. CE. ${ }^{23}$

Despite its blatantly pejorative tone, Agatharchides's observations seem to find a resonance in the archaeological data as iconographic scenes often depict naked characters. Male or female, one common trait shared by these individuals seems to be their young age. In the documentation assembled in the Karanog cemetery, a young undressed boy can appear as a shepherd, ${ }^{24}$ painted on a ceramic bowl, or as the son (?) of a noble lady on her funerary stelae ${ }^{25}$ (cf. Fig. 4). An undressed girl is also depicted on its own

${ }^{22}$ Bille et al. 2010, esp. the editors' introduction (3-22) and L. Meskell's commentary (207-213). For the ambiguity of archaeological sources, see Gero 2007.

${ }^{23}$ Trans. T. Eide et al., Fontes Historiae Nubiorum II, 1996, $\mathrm{n}^{\circ} 143,650-655$.

${ }^{24}$ Pennsylvania University Museum of Anthropology and Archaeology E8451.

${ }^{25}$ Cairo Egyptian Museum, JE 40229. Reproduced in Wenig $1978,205-206, n^{\circ} 127$. funerary stelae ${ }^{26}$ or standing behind her parents in a tribute scene engraved on a bronze bowl. ${ }^{27}$ Far from the "uncivilised" image conveyed by the classical authors, the naked body was not devoid of adornments: jewellery, hair dress, scarification and tattoos, all participated in the body acculturation process. ${ }^{28}$ One amongst others, clothing was not an obligatory component of body practices and its absence seems to have been a marker of children, regardless of social class. ${ }^{29}$

\section{Girdles and leather clothing}

Another point raised by Agatharchides is the use of animal skins or other animal by-products. Many grave discoveries include fine leather fragments, fur, shell pendants, and ostrich eggshell beads corroborating parts of the author's descriptions. Girdles, made of beads or twisted leather, are common occurrences in cemeteries throughout the whole Meroitic territory, regardless of the period or the age and gender of the deceased. Long beaded belts, made of ostrich eggshell discs, cauris shells, semi-precious stones, glass or faience, decorated the waist of many individuals buried at Meroe, for example. ${ }^{30}$ The same observation was made all the way up north, in Lower Nubia, by excavators working at Semna South. ${ }^{31}$ Different traditions appear in the Southern regions, particularly at Gebel Moya, where this practice seems to have been restricted to young women and girls. ${ }^{32}$ In general, we cannot know for certain how any of these belts were worn, alone or associated with another piece of clothing such as a loincloth which could have covered the genitals. Of various size and pattern, the girdles offered a very moderate degree of protection from the elements and from view. Their first apparent role was to accentuate the waist of both men and women, thereby drawing attention to this area of the body.

Animal skins were also used to manufacture garments. No study has been exclusively focused on leather costumes, but a cursory survey of the Meroitic leather findings confirm the importance of this material for the creation of shoes, quivers, bags, containers, animal harnesses, and last but not least, garments. ${ }^{33}$ Thin tanned pieces of leather were used to cover the mid-section, as a loincloth or a skirt. A well-preserved specimen discovered at Sai, in situ on a child's skeleton, shows

${ }^{26}$ Cairo Egyptian Museum, JE 32545. Reproduced in Woolley and Maciver 1910, Pl. 13, $\mathrm{n}^{\circ} 7079$.

${ }^{27}$ Cairo Egyptian Museum, JE 41017. Reproduced in Wildung $1997,382$.

${ }^{28}$ MacCann 2010.

${ }^{29}$ Nudity also extended to other classes of the population, to a various degree. Kings, queens, princes, and noble men and women are generally represented with a bare chest.

${ }^{30}$ Dunham 1963.

${ }^{31}$ Žabkar and Žabkar 1982, 23.

${ }^{32}$ Addison 1949.

${ }^{33}$ Leather fragments were often noted by archaeologists excavating graves, but rarely detailed or formally documented. Late Meroitic and Post-Meroitic sites are particularly rich in leather material, e.g. the cemeteries of Ballana, Holland 1983. 


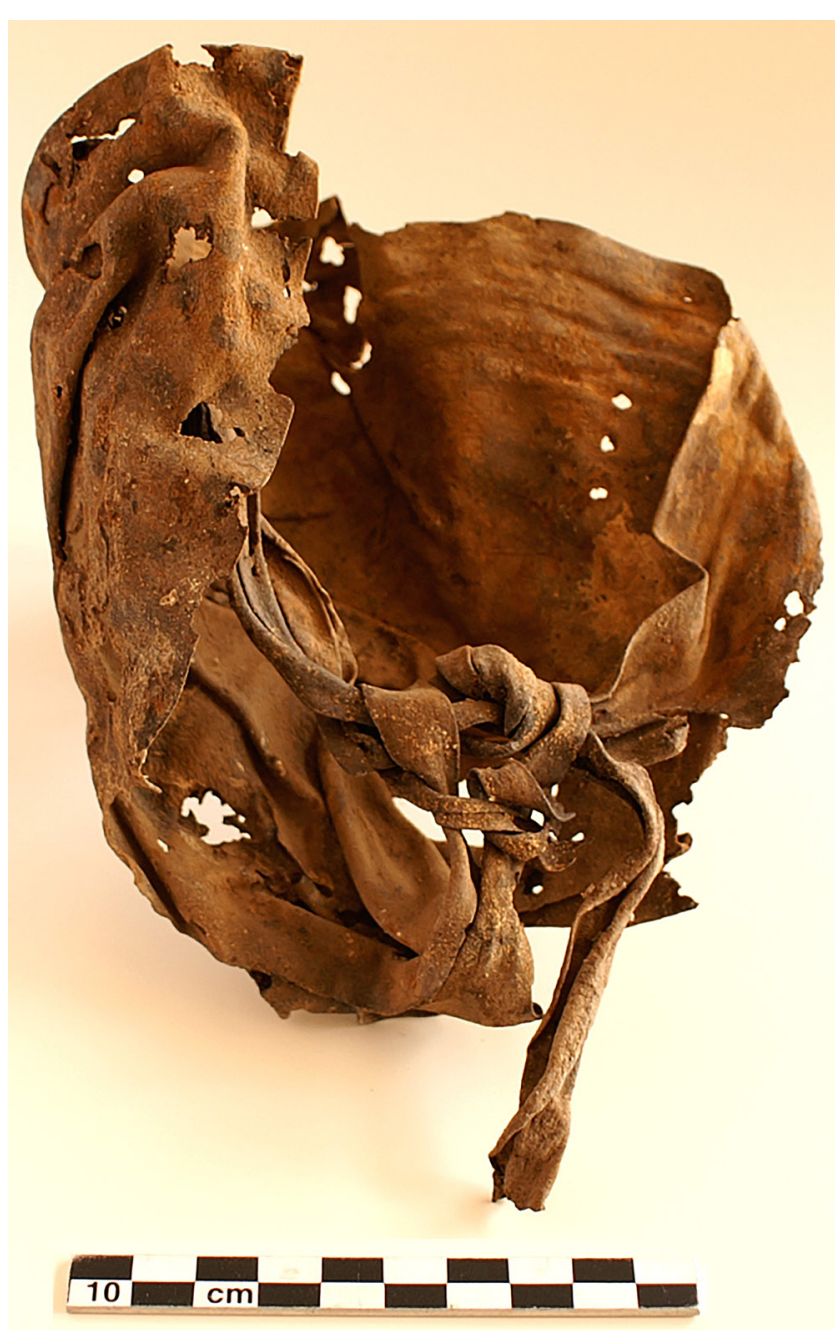

Fig. 2. Leather loincloth found in situ in the child grave T331, in cemetery 8-B-5.A on Saï Island. (C) Sai Island Archaeological Mission. Photo E. Yvanez.

a rough triangular shape with long thongs at each of the extremities, passed between the legs and fastened around the waist as a loincloth (Fig. 2). Other smaller fragments found in the same cemetery 8-B-5.A display remains of stitching (holes or thread) and decorative surface treatments. Later inhumations dated to the Post-Meroitic period (c. 350-550 CE) have even revealed entire costumes made of leather. It was notably the case in the Atbara region, north of Meroe, where several males and females have been discovered at Gabati wearing a long leather skirt sometimes completed by a short tunic or a headdress made of the same material. ${ }^{34}$ The use of leather in the Meroitic clothing repertoire therefore appears quite important and varied, but unfortunately remains undervalued in the literature. And yet, often associated with other garments made of textiles, beaded girdles or jewellery, leather garments plainly belong to the realm of Meroitic costume practices.

\footnotetext{
${ }^{34}$ Edwards 1998, 72-99, 125
}

The high value of textile fabrics

It appears now clearly that textile clothing was not a very wide-spread phenomenon in ancient Sudan. Besides cultural traditions, the high cost of textiles might have been a decisive factor. Before even considering the raw material needed, weaving is a "costly" process as it is a slow and laborious craft that requires a lot of time and a specialised know-how, to spin and weave the fibres. ${ }^{35}$ In arid climatic conditions with scarcity or restricted seasonal water access, producing fibres - either vegetal or animal - requires vast resources. In an economy of extensive land use, diverting these resources away from food production is a significant decision. In Lower Nubia, where most of our textile assemblages originate, cotton represents up to $85 \%$ of the textile corpus discovered at Classic to Late Meroitic sites (c. 0-400 CE). ${ }^{36}$ It is also attested in the Meroe region, under different forms such as textiles and archaeobotanical remains. Cotton production was recognised in Lower Nubia, in the vicinity of Qasr Ibrim, and hypothetically identified along the Butana wadis in Central Sudan. It necessitated large amounts of water (in an already extremely arid region in the case of Nubia), developed irrigation systems, and the mobilisation of an important workforce during the vital sorghum and millet harvest season. ${ }^{37}$ Growing cotton in Meroitic Sudan was certainly an agricultural choice with great consequences. We can therefore imagine the high value of cotton fibres and it is perhaps not surprising to find it so widely used in elite costumes. We do not dispose of much evidence regarding the hypothetical cost of woollen fibres, made from goat, sheep or camel hair. Since wool was not the only resource extracted from animals, and animal husbandry was commonly practiced in riverine and semi-arid areas of Sudan, we can infer easy access to woollen products. In effect, it was widely used for textile production in the Early Meroitic period, and then during the Post-Meroitic period which saw its resurgence. ${ }^{38}$ It is also worth mentioning a possible use of other vegetal fibres, notably wild ones. Three textile fragments, found in the el-Geili cemetery and dated to the $2^{\text {nd }}$ century BCE, were made of aloe ferox and kapok, respectively coming from the agave plant and baobab fruits. ${ }^{39}$ The excavators explained this original finding by the identity of the textile's owners as semi-nomadic pastoralists. This last case exemplifies the tendency to oppose animal and wild fibres to cotton or other plant fibres such as linen. While the first ones are associated with pastoralism and nomadic populations, the other are perceived as products of deliberately organised agricultural practices linked to the sedentary Meroitic ruling class. Generalised

\footnotetext{
${ }^{35}$ For a good description of the textile chaîne opératoire, see Anderson Strand 2012.

${ }^{36}$ Mayer-Thurman and William 1979, 36; Yvanez 2012; Yvanez 2015.

${ }^{37}$ Fuller 2014.

${ }^{38}$ Mayer-Thurman and William 1979, 36-37.

${ }^{39}$ Caneva and Scala 1988.
} 


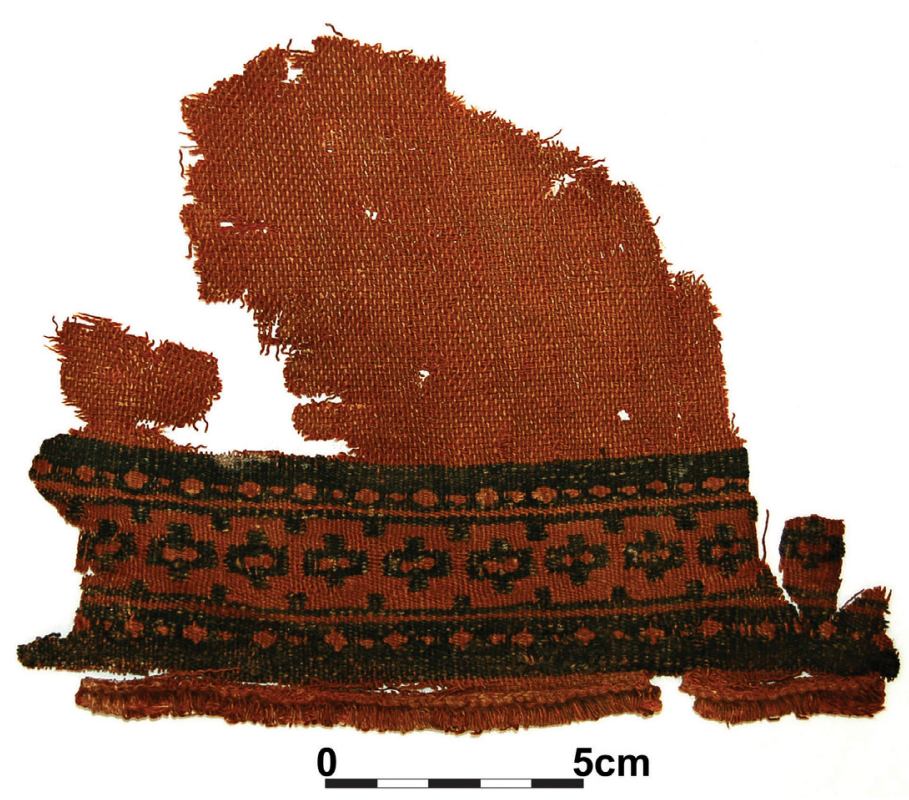

Fig. 3. Cotton textile from Karanog, in half-basket weave, showing a blue tapestry band with a frieze of offering tables bordered with crenelated and beaded lines. The Textile Museum, Washington, D.C., 77.1, Acquired by George Hewitt Myers in 1934. Photo E. Yvanez.

to the entire Meroitic textile production, this caricatured dichotomy overstates the available data and creates an undesirable hierarchy of material and, consequently, of people. Nevertheless, it stands true that cotton and cotton fabrics are still exclusively appearing as a strong component of the elite material world.

\section{Cotton textiles and elite dress}

First of all, the costly production of cotton fibres could only have been possible with the support, if not supervision, of the authorities. The necessary irrigation systems, the management of a different agricultural calendar, the traces of cotton seeds within official towns, and the standardisation of spinning tools, all seem to point to a degree of centralised cotton production and control. ${ }^{40}$ The cotton textiles themselves seem to corroborate this hypothesis, as their great stylistic homogeneity resonates well with the idea of an organised weaving industry capable of producing a small surplus of textiles, similar in form, décor, and quality of execution. The distinct textile style developed during the $1^{\text {st }}, 2^{\text {nd }}$ and $3^{\text {rd }}$ centuries CE is particularly well illustrated in the Karanog cemetery, which welcomed the graves of the highest Nubian administrative officials, the viceroys of Nubia, and their relatives. ${ }^{41}$ All 30 of the different textiles I studied for this site are made of cotton and spun in the same counter clockwise direction. The fabrics were likely woven on a warp-weighted loom, in simple or extended tabby. The thread diameter is generally around $0.5 \mathrm{~mm}$, but can sometimes be smaller $(0.2-$ $0.3 \mathrm{~mm}$ ). The density of the weave varies slightly depending on the frequent use of tapestry, but a balanced tabby is often

\footnotetext{
${ }^{40}$ Fuller 2015, 45-47.

${ }^{41}$ Török 2002, 67.
}

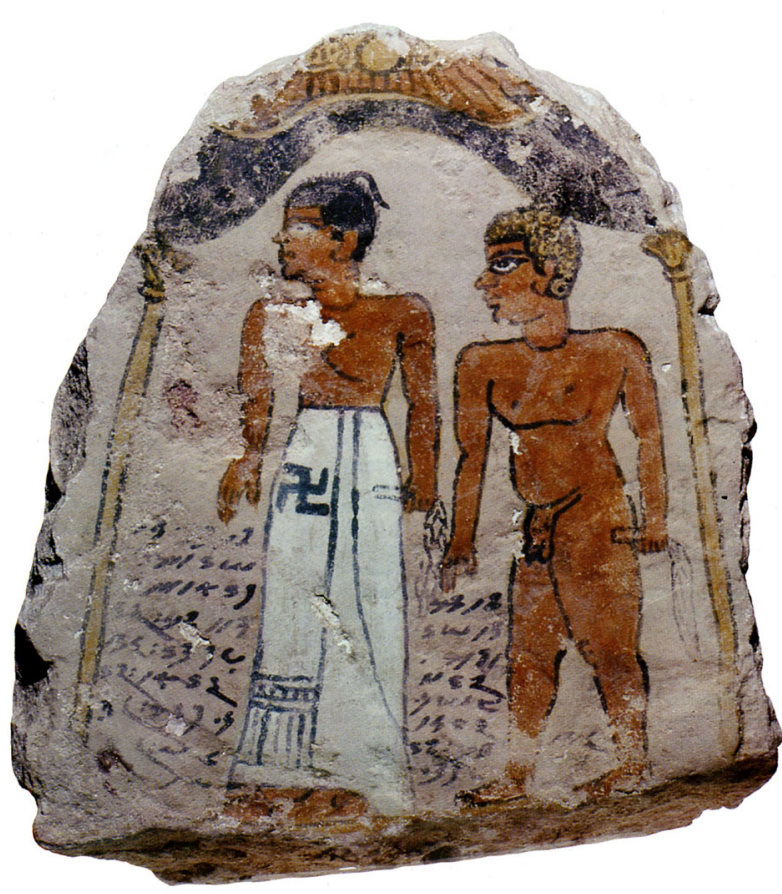

Fig. 4. Painted stelae from Karanog, grave 275. Cairo museum JE40229. Reproduced from Wenig 1978, n 127, 206.

woven with 9 or 10 threads per $\mathrm{cm}$ in each warp and weft direction. All but three fabrics bear ornamentation of some kind: fringes, tassels, openwork borders, stripes, embroideries or tapestry patterns. The décors exploit variations of light and dark blues on a natural colour ground fabric. The motives come from the local Kushite iconographic repertoire, with ankh signs, lotus flowers or offering tables (Fig. 3). There are also those inspired by the Hellenistic world and reinterpreting on cotton textiles the swastikas, meanders and 


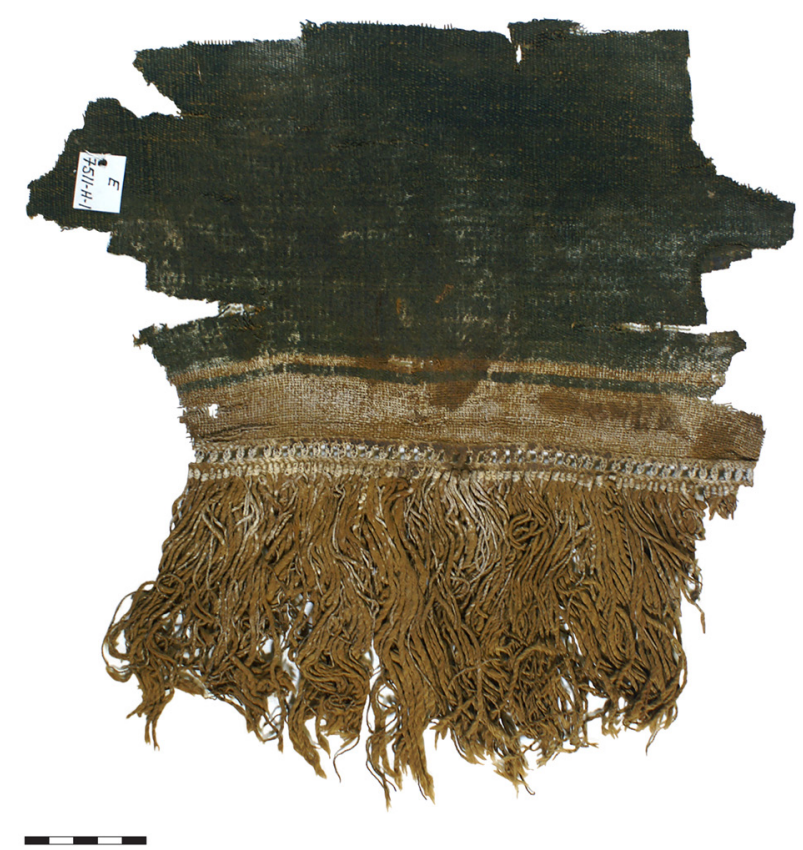

Fig. 5. Blue and white (originally) cotton textile from Karanog, ending by an open work border and long fringed tassels. Courtesy of Penn Museum, image E7511H. Photo E. Yvanez.

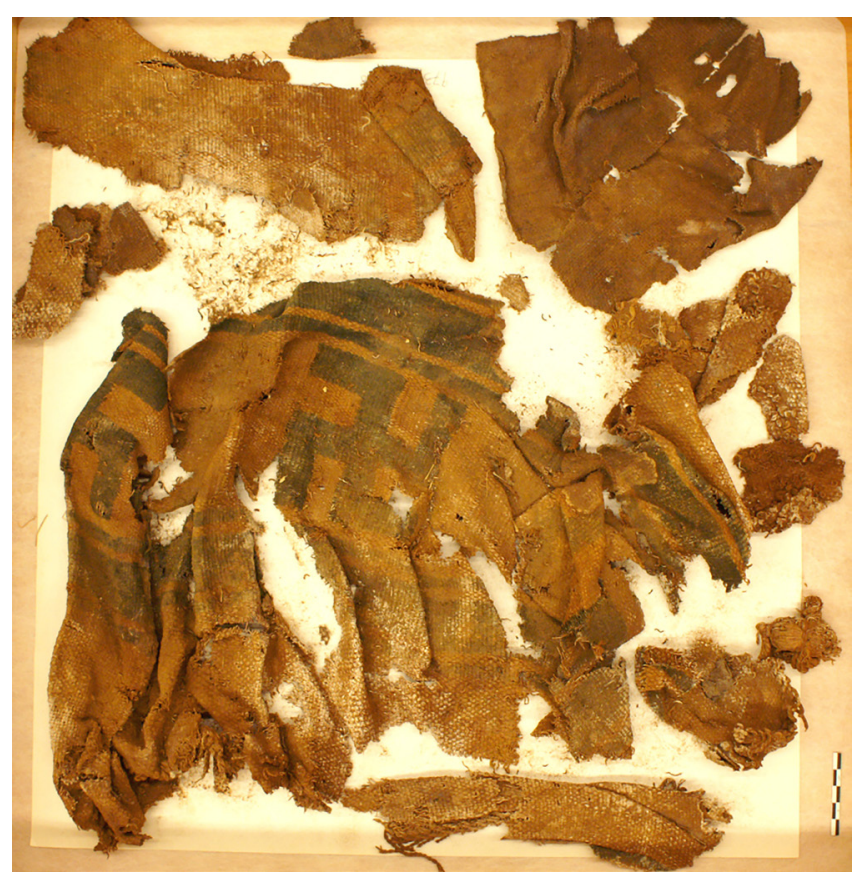

Fig. 6. Large rectangular cotton fabric with blue swastikas and stripes, from Gebel Adda, Royal Ontario Museum 973.24.3528. Photo E. Yvanez CROM.

gammadae used on Egyptian tunics. In a way, this "classical" Meroitic textile style transcribes in fabric the cultural syncretism operated throughout the kingdom during the same period and typical of the official Meroitic arts. ${ }^{42}$ The presence

${ }^{42}$ Syncretism between the African and Saharan roots of the Nile regions, and the Egypto-Kushite iconographic and religious heritage, as well as the Greco-Roman repertoire. Elements of each of such a cohesive style, congruent with the rest of the artistic production, leads us to question the existence of specialised or semi-specialised weavers able to answer the well-defined and consistent demands of the elite class.

can be seen mixed in the same art forms: statuary, ceramics, jewelry, etc. Cf. Baud 2010a. 

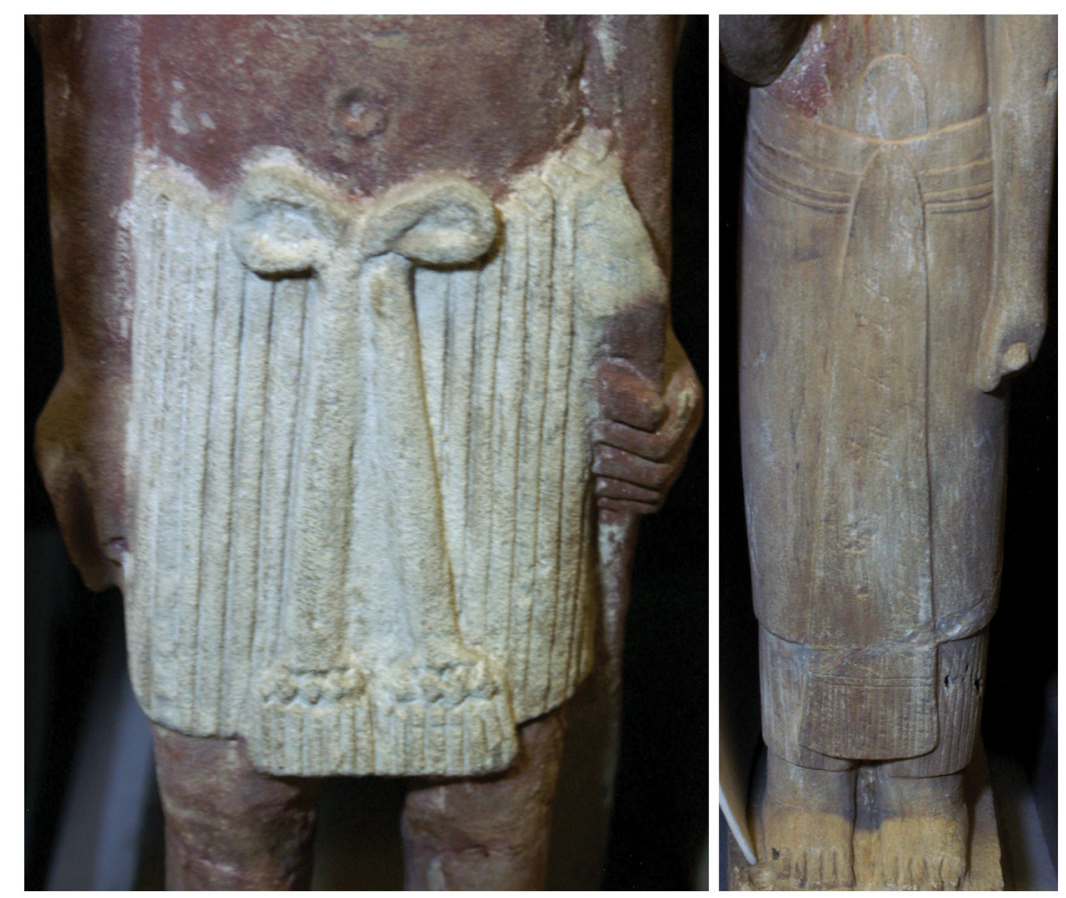

Fig. 7. Detail of the long skirt and decorative apron worn by two male officials on their funerary $b a$-statues from Karanog. Courtesy of Penn Museum, image E7010 and E7018. Photo E. Yvanez.

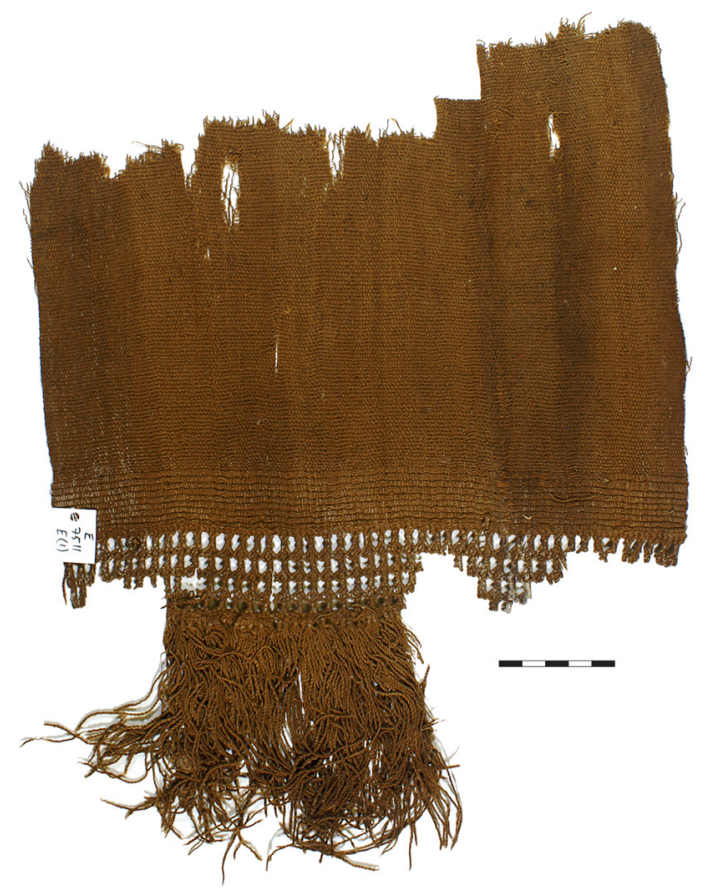

Fig. 8. Fragment of a cotton sash from Karanog, finished by an openwork border and long tasselled fringes. Courtesy of Penn Museum, image E7511E1. Photo E. Yvanez.

Well-conveyed by the textiles' quality, the importance of costume for the self-definition of the administrative and religious officials is also blatant in their iconographic representations. Depicted on private monuments, such as funerary stelae and $b a$-statues, the nobles are shown wearing distinctive pieces of clothing that, luckily for us, offer very good parallels to the preserved cotton textiles. Examples of direct comparisons between fabrics and iconography are too numerous to list, but well-chosen cases can usefully illustrate the benefits of establishing an open dialogue between sources. Because of the great preservation of Nubian textiles, I have elected to stay close to Karanog, selecting documents 
dated to the $2^{\text {nd }}-3^{\text {rd }}$ centuries CE, but many iconographic representations from the Meroe region would attest the generalisation of the elite costume to the whole of the Meroitic kingdom. ${ }^{43}$

The first example is a sandstone painted funerary stelae discovered at Karanog in the grave of a woman (G275) ${ }^{44}$. It shows a woman dressed in a long white skirt and followed by a naked man (Fig. 4). The skirt appears to be a wraparound garment, either made with two layers of textiles, or wrapped twice around the waist. The back trails slightly, as it frequently does on women skirts since the Napatan period. It closes on the side of the body, with a slightly shorter back panel decorated with two short horizontal stripes on the posterior, and a long front panel showing an elaborate décor. The top shows a large swastika pattern and on the bottom a decorative band greatly resembles an openwork border and long fringes. ${ }^{45} \mathrm{~A}$ fragment of a large blue textile from Karanog shows very similar elements, displaying an openwork of small vertical hatches and a bushy border of long fringes (Fig. 5). Another piece from the neighbouring site of Gebel Adda exhibits a frieze of rather large swastika patterns, made in a tapestry technique with blue threads on a natural (originally white?) colour background (Fig. 6).

Once again using the Karanog documentation, we can illustrate the significant use of fringed belts or sashes in the male costume. Two of the $b a$-statues found at the site show such garments tied around the waist on top of a skirt, with the two long pendants hanging down the front, like an ornamental apron (Fig. 7). Finished by long fringes, these belts reached the bottom of the skirt, at the knees or all the way down the calves. On these particular statues, the fringes seem to be preceded by a decorative horizontal band, probably formed by an openwork. A well preserved cotton sash, $26 \mathrm{~cm}$ wide, could have very well fulfilled this type of function (Fig. 8). The sash ends with an elaborate openwork, drawing a lattice of diamonds and vertical hatches, and is also finished by long tasselled fringes. Outside of Karanog, the correspondence between Nubian textile finds and the pictures of male officials is particularly well illustrated by the relief of the Meroitic chamber, in the Philae temple, which shows a procession of Meroitic diplomatic envoys. ${ }^{46}$ The growing interpretation of this body of material is the existence of a true clothing uniform sanctioning the assumption of administrative and religious duties ${ }^{47}$, notably linked to the cursus honorum of viceroys and priests of Isis.

\section{Conclusion}

We can easily imagine the striking effect caused by the bright costumes of the nobles, in a world where body coverings were rare and made of leather girdles and loincloths or beaded belts. Heavily decorated by hanging ornaments and religious patterns, using two colours rarely seen in everyday life but often painted on temple walls, these garments and their owners must have appeared very special in the surrounding landscape.

While textile production was by no means exclusively restricted to the elite members of the Meroitic society, I would like to propose the existence of a luxury production of high-quality cotton fabrics primarily intended to dress the officials of the kingdom. This luxury production would have rested on the development of cotton agriculture, sanctioned by the royal power, and the possible control of resources, weaving processes and redistribution. It would have involved experienced weavers working in polyvalent industrial areas and producing a limited output of high-quality fabrics. Very distinctive in form and in style, these fabrics would have been used to create garments for the elite in charge of the administrative and religious organisation. Worn by many individuals all throughout the kingdom, the garments became a true uniform immediately associating the wearers to their function and status. In the fabrics themselves, from the material used to their manufacturing techniques and décor, the clothing culture developed for the elite embodied their close relationship to the royal power, available for all to see wrapped around their very body.

\section{Bibliography}

Adams N. K. 1987. Textile Remains from a Late Temple in Egyptian Nubia. "Ars Textrina” 8, 85-124.

Adams N. K. 1989. Meroitic High Fashions: Examples from Art and Archaeology. "Meroitica” 10, 747-755.

Adams N. K. 2007. Political Affinities and Economic Fluctuations: The Evidence from Textiles. In: C. Gillis, M.-L. Nosch (eds.), Ancient Textiles, Production, Craft and Society. Proceedings of the First International Conference on Ancient Textiles, Held at Lund Sweden and Copenhagen, Denmark, on March 19-23, 2003. Ancient Textiles Series 1. Oxford, 201-207.

\footnotetext{
${ }^{43}$ It is particularly apparent in the reliefs sculpted on the chapel walls of the royal pyramids, Chapman and Dunham 1952.

${ }^{44}$ For complete bibliography and reference, see Wenig 1978, $\mathrm{n}^{\circ} 127$.

${ }^{45}$ For a discussion of this method and its iconographic representation, see Adams 1989.
}

\footnotetext{
${ }^{46}$ See previous studies of the envoy's costumes: Adams 2015; Pompei 2015; Yvanez, forthcoming. ${ }^{47}$ Yvanez 2018.
} 
Adams N. K. 2015. Images of Men in the 'Ethiopian Chamber' in the Isis Temple at Philae: What Were They Wearing? In: M. Zach (ed.), The Kushite World. Proceedings of the $11^{\text {th }}$ International Conference for Meroitic Studies - Vienna, 1-4 September 2008. "Beiträge zur Sudanforschung": Beiheft 9. Berlin, 447-454.

Adams W. Y., Adams N. K. 2013. Qasr Ibrim: The Ballaña Phase. Egypt Exploration Society: Excavation Memoir 104. London.

Addison F. 1949. Jebel Moya. The Wellcome Excavations in the Sudan 2. Oxford.

Andersson Strand E. 2012. The Textile Chaîne Opératoire: Using a Multidisciplinary Approach to Textile Archaeology with a Focus on the Ancient Near East. "Paléorient" 38 (1-2), Dossier thématique / Thematic file, C. Breniquet, M. Tengberg, E. Andersson, M.-L. Nosch (eds.), Préhistoire des Textiles au Proche-Orient / Prehistory of Textiles in the Near East, 21-40.

Andersson Strand E., Nosch M.-L. (eds.) 2015. Tools, Textiles and Contexts. Investigating Textile Production in the Aegean and Eastern Mediterranean Bronze Age. Ancient Textiles Series 21. Oxford, Philadelphia.

Barber E. J. W. 2007. Weaving the Social Fabric. In: C. Gillis, M.-L. Nosch (eds.), Ancient Textiles. Production, Craft and Society. Proceedings of the First International Conference on Ancient Textiles, Held at Lund Sweden and Copenhagen, Denmark, on March 19-23, 2003. Ancient Textiles Series 1. Oxford, 173-178.

Baud M. (ed.) 2010a. Méroé. Un empire sur le Nil. Catalogue de l'exposition du Louvre. Paris, Milan.

Baud M. 2010b. Méroé, un monde urbain. In: M. Baud (ed.), Méroé. Un empire sur le Nil. Paris, Milan, 211-217.

Bille M., Hastrup F., Sørensen T. F. (eds.) 2010. An Anthropology of Absence: Materializations of Transcendence and Loss. New York.

Caneva I., Scala G. 1988. Textiles in the Geili Cemetery. In: I. Caneva (ed.), El Geili: The History of a Middle Nile Environment 7000 B.C.-A.D. 1500. British Archaeological Reports. International Series 424. Oxford, 303-318.

Chapman S. E., Dunham D. 1952. Decorated Chapels of the Meroitic Pyramids at Meroe and Barkal. Royal Cemeteries of Kush III. Boston.

Crawford O. G. S., Addison F. 1951. Abu Geili and Saqqadi and Dar el-Mek. The Wellcome Excavations in the Sudan 3. London.

Driskell B. N., Adams N. K., French P. G. 1989. A Newly Discovered Temple at Qasr Ibrim Preliminary Report. "Archéologie du Nil Moyen" 3, 11-53.

Dunham D. 1963. The West and South Cemeteries at Meroe. Royal Cemeteries of Kush V. Boston.

Edwards D. N. 1996. Appendix 3. The Meroitic Settlement on Tila Island (16-J-20). In: D. N. Edwards, The Archaeology of the Meroitic State: New Perspectives on Its Social and Political Organisation. Cambridge Monographs in African Archaeology 38. British Archaeological Reports International Series 640. Oxford, 106-114.

Edwards D. N. 1998. Gabati. A Meroitic, Post-Meroitic and Medieval Cemetery in Central Sudan. London.

Edwards D. N. 2004. The Nubian Past. An Archaeology of the Sudan. London, New York.

Eide T., Hägg T., Pierce R. H., Török L. 1996. Fontes Historiae Nubiorum. Textual Sources for the History of the Middle Nile Region between the Eight Century B.C. to the Sixth Century A.D. II. From the Mid-Fifth to the First Century B.C. Bergen.

Evina M. 2010. Une double tradition céramique. In: M. Baud (ed.), Méroé. Un empire sur le Nil. Paris, Milan, 105-113.

Fuller D. 2014. Agricultural Innovation and State Collapse in Meroitic Nubia: The Impact of the Savannah Package. In: C. J. Steven, S. Nixon, M. A. Murray and D. Fuller (eds.), Archaeology of African Plant Use. London, 165-177.

Fuller D. 2015. The Economic Basis of the Qustul Splinter State: Cash Crops, Subsistence Shifts, and Labour Demands in the Post-Meroitic Transition. In: M. Zach (ed.), The Kushite World. Proceedings of the $11^{\text {th }}$ International Conference for Meroitic Studies - Vienna, 1-4 September 2008. "Beiträge zur Sudanforschung”: Beiheft 9. Berlin, 33-60.

Gero J. M. 2007. Honoring Ambiguity / Problematizing Certitude. "Journal of Archaeological Theory" 14, $311-327$.

Gillis C., Nosch M.-L. (eds.) 2007. Ancient Textiles, Production, Craft and Society. Proceedings of the First International Conference on Ancient Textiles, Held at Lund Sweden and Copenhagen, Denmark, on March 19-23, 2003. Ancient Textiles Series 1. Oxford.

Gleba M. 2008. Textile Production in Pre-Roman Italy. Ancient Textiles Series 4. Oxford.

Holland T. A. 1983. Noubadian X-Group Remains from Royal Complexes in Cemeteries $Q$ and 219 and from the Private Cemeteries $Q, R, V, W, B, J$, and $M$ at Qustul and Ballana, OINE IX. Chicago.

Humphris J. 2014. Post-Meroitic Iron Production: Initial Results and Interpretations. "Sudan and Nubia” 18, 121-129.

Jacquet J. 1971. Remarques sur l'architecture domestique à l'époque méroïtique: documents recueillis sur les fouilles d'Ash-Shaukan. "Beiträge zur ägyptischen Bauforschung und Altertumskunde" 12, 121-131.

Kemp B. J., Vogelsang-Eastwood G. 2001. The Ancient Textile Industry in Amarna. Egypt Exploration Society: Excavation Memoir 68. London.

MacCann E. 2010. Body Modification in Ancient Sudan. In: W. Godlewski, A. Lajtar (eds.), Between the Cataracts. Proceedings of the 11 $1^{\text {th }}$ International Conference for Nubian Studies Warsaw University 27 August-2 September 2006. Polish Archaeology in the Mediterranean Supplement Series 2, 2.2, Warsaw, 775-779. 
Mayer-Thurman C. C., Williams B. (eds.) 1979. Ancient Textiles from Nubia: Meroitic, X-Group and Christian Fabrics from Ballana and Qustul. Chicago.

Pompei A. 2015. Meroitic Priest Long Garments Decorated by Falcon or Vulture. In: M. Zach (ed.), The Kushite World. Proceedings of the $11^{\text {th }}$ International Conference for Meroitic Studies - Vienna, 1-4 September 2008. "Beiträge zur Sudanforschung": Beiheft 9. Berlin, 565-572

Shinnie P. L., Anderson J. R. 2004. The Capital of Kush II. Merö Excavations 1973-1984. "Meroitica” 20. Wiesbaden.

Shinnie P. L., Bradley R. 1980. The Capital of Kush I. Meroë Excavations 1965-1972. "Meroitica” 4. Berlin.

Török L. 1977. Inquiries into the Administration of Meroitic Nubia: I-II. "Orientalia" 46, 34-50.

Török L. 1979. Economic Offices and Officials in Meroitic Nubia (A Study in Territorial Administration of the Late Meroitic Kingdom). Studia Aegyptiaca 5. Budapest.

Török L. (ed.) 1997. Meroe City, an Ancient African Capital. John Garstang’s Excavations in the Sudan I-II. Egypt Exploration Society: Occasional Publications 12. London.

Török L. 2002. Kinship and Decorum: (Re-)constructing the Meroitic Elite. "Mitteilungen der Sudanarchäologischen Gesellschaft zu Berlin" 13, 60-84.

Welsby D. A. 1996. The Kingdom of Kush, the Napatan and Meroitic Empires. London.

Wenig S. 1978. Africa in Antiquity II. The Arts of Ancient Nubia and the Sudan. The Catalogue. Brooklyn.

Wildung D. (ed.) 1997. Soudan, Royaumes sur le Nil. Catalogue de l'exposition de l'Institut du Monde Arabe. Paris.

Woolley C. L., Maciver D. R. 1910. Karanog: The Romano-Nubian Cemetery, Eckley B. Coxe Junior Expedition to Nubia 4. Philadelphia.

Yvanez E. 2012. Les textiles des nécropoles mérö̈tiques de Saï. "CRIPEL” 29, 331-344.

Yvanez E. 2015. De fil en aiguille. Aspects de l'artisanat textile méroïtique. "Egypte Afrique et Orient" 78, 63-66.

Yvanez E. 2016. Spinning in Meroitic Sudan. Textile Implements from Abu Geili. "Dotawo, a Journal of Nubian Studies" 3, $153-178$.

Yvanez E. 2018. Se vêtir à Djebel Adda. Nouvelles perspectives de recherche sur l'identité culturelle en Nubie méroïtique. In: M. Maillot, G. Choimet (eds.), Actualités archéologiques françaises au Soudan. Routes de l'Orient Hors-série 3, $103-123$.

Yvanez E. forthcoming. Textiles Activities in Context. An Example of Craft Organisation in Meroitic Sudan. In: P. Onderka, Proceedings of the 12 ${ }^{\text {th }}$ International Conference for Meroitic Studies, National Museum, Praha 2017.

Žabkar L. V., Žabkar J. J. 1982. Semna South. A Preliminary Report on the 1966-68 Excavations of the University of Chicago Oriental Institute Expedition to Sudanese Nubia. "Journal of the American Research Center in Egypt" 19, 7-50.

\section{Streszczenie}

\section{Ubierając elity? Wzorce produkcji i użytkowania tekstyliów w starożytnym Sudanie i Nubii}

W królestwie Meroe (300 p.n.e.-50 n.e.) rozwinęła się unikalna tradycja włókiennicza, której śladem dziś są setki fragmentów tkanin, narzędzia włókiennicze oraz ikonografia. Te liczne pozostałości stanowią cenne źródło dla studiów nad sposobami organizacji produkcji włókienniczej i użytkowaniem tekstyliów w społeczeństwie meroickim. Połączenie informacji o narzędziach włókienniczych z ich kontekstem archeologicznym pozwoliło na rozpoznanie skali produkcji włókienniczej i jej lokalizacji na różnych stanowiskach. Wytwórczość tekstylną w Meroe cechowała różnorodność, która odzwierciedla złożoność społeczną i etniczną tego królestwa. Przeprowadzono także porównanie danych pochodzących z osad z gotowymi wyrobami - tkaninami i ubiorami - odkrywanymi w grobach czy przedstawianymi w reliefie i rzeźbie, łącząc w ten sposób tekstylia z indywidualnymi osobami, które je nosiły. Omówiono także rolę elit, zarówno jako organizatorów produkcji i konsumentów określonych produktów włókienniczych, jak i urzędowych zarządców produkcji kontrolowanej przez państwo meroickie. 